$\left.47_{3}: b: 1,5\right)$ proved the $O$ antigen of $S$. chersina to be complex and composed of $47_{1}$ and $47_{3}$. Therefore, S. chersina shares the same O complex with S. kaolack, S. phoenix, and S. lyon, i.e., with the majority of the O-47 members. [See Kauffmann (Acta Pathol. Microbiol. Scand. 56:343$351,1962)$ for further information about the $\mathrm{O}$ group 47 .]

When S. chersina was placed in tubes of semisolid medium which contained $\mathrm{z}$ serum for the isolation of phase 2, migration through the medium was noted after 24 to $48 \mathrm{hr}$ of incubation. The spreading growth was agglutinated by the $\mathrm{H}$ antiserum $\mathrm{z}_{6}$. Antigen relations exist between the $\mathrm{z}_{6}$ fraction of $S$. chersina and the $\mathrm{Ha}$ antigen.

$S$. chersina has the formula $47_{1}, 47_{3}: z: z_{6} . S$. chersina was primarily resistant to: ampicillin $(25 \mu \mathrm{g})$, cloxacillin $(5 \mu \mathrm{g})$, oxacillin $(5 \mu \mathrm{g})$, methicillin $(10 \mu \mathrm{g})$, phenethicillin $(5 \mu \mathrm{g})$, tetracycline phosphate $(50 \mu \mathrm{g})$, novobiocin $(30 \mu \mathrm{g})$, erythromycin $(6 \mu \mathrm{g})$, matromycin $(15 \mu \mathrm{g})$, and spiramycin $(30 \mu \mathrm{g})$. It was sensitive to streptomycin $(50 \mu \mathrm{g})$, chloramphenicol $(20 \mu \mathrm{g})$, neomycin $(50$ $\mu \mathrm{g})$, framycetin (100 $\mu \mathrm{g})$, and kanamycin (30 $\mu \mathrm{g})$. The antibiogram was carried out on paper discs with the amounts stated.

The 0-1 phage disintegrates only about $30 \%$ $S$. chersina colonies. Therefore, $S$. chersina is only partially sensitive to the O-1 phage. Similar to S. calvinia (Brede, Zentr. Bakteriol. Parasitenk. Abt. I Orig. 188:137, 1963), the O-1 phage resistance of $S$. chersina is even stronger than in the case of $S$. zanzibar, until the present the usual control species for $0-1$ phage tests. These facts were confirmed by H. Fry, Bern, Switzerland, to whom I express my thanks for doing control tests.

I wish to thank Joan Taylor, London, England; P. R. Edwards, Atlanta, Ga.; and F. Kauffmann, Copenhagen, Denmark, for confirming the formula of S. chersina.

This investigation was supported in part by a research grant from the Council of Scientific and Industrial Research, Pretoria.

\title{
ABSENCE OF LETHAL EFFECT OF PENICILLIN IN GERM-FREE GUINEA PIGS
}

\section{WALTER L. NEWTON ${ }^{1}$ HARRY G. STEINMAN, AND MICHAEL W. BRANDRISS}

Laboratory of Germfree Animal Research and Laboratory of Clinical Investigations, National Institute of Allergy and Infectious Diseases, National Institutes of Health, U.S. Public

Health Service, Bethesda, Maryland

Received for publication 20 March 1964

The lethality of small doses of penicillin for the guinea pig is in marked contrast to its lack of toxicity in other animal species (Hamre et al., Am. J. Med. Sci. 206:642, 1942). Earlier investigations seemed to indicate that the antibiotic was directly toxic to the guinea pig (Cormia et al., J. Invest. Dermatol. 7:261, 1947). Later studies suggested, however, that death was the result of a harmful change in the intestinal flora (De Somer et al., Antibiot. Chemotherapy $5: 463,1955)$. If the toxicity of small doses of penicillin were a secondary effect of a disturbance of the normal floral balance, then animals without a bacterial flora might

${ }^{1}$ Present address: Division of Research Services, National Institutes of Health, Bethesda, Md. be expected to be less affected. To test this conclusion, a comparison was made of the lethality of penicillin for both conventional and germ-free guinea pigs. Our results confirm those recently reported by Formal et al. (Nature 198:712, 1963), who performed a similar experiment.

Both conventional and germ-free guinea pigs were from the National Institutes of Health general purpose colony and weighed from 250 to $350 \mathrm{~g}$. Aqueous penicillin $\mathrm{G}$ (potassium salt) was given as a single intraperitoneal injection. In the first series of experiments, varied doses of penicillin were given to conventional animals only. In the second series of experiments, conventional and germ-free animals were given $120 \mathrm{mg} / \mathrm{kg}$ of penicillin. 
TABLE 1. Mortality of conventional 300-y guinea pigs given single injections of potassium penicillin $G$ intraperitoneally

\begin{tabular}{ccc}
\hline $\begin{array}{c}\text { Dosage } \\
\text { (mg/kg of body wt) }\end{array}$ & No. of expt & $\begin{array}{c}\text { No. of deaths/ } \\
\text { no. injected }\end{array}$ \\
\hline $3.75-7.5$ & 2 & $0 / 8$ \\
15 & 4 & $8 / 18$ \\
30 & 2 & $4 / 9$ \\
60 & 4 & $13 / 18$ \\
120 & 3 & $10 / 24$ \\
240 & 2 & $8 / 18$ \\
\hline
\end{tabular}

TABLE 2. Comparative mortality of conventional and germ-free guinea pigs after a single injection of potassium penicillin $G$ intraperitoneally at $a$ dosage of $120 \mathrm{mg} / \mathrm{kg}$ of body weight

\begin{tabular}{ccccc}
\hline Animal type & Expt no. & Mortality & & Total \\
\cline { 1 - 3 } Conventional & 1 & $2 / 12$ & \\
& 2 & $6 / 10$ & \\
& 3 & $10 / 10$ & \\
& 4 & $4 / 10$ & & $22 / 42$ \\
& & & \\
Germ-free & 1 & $0 / 11^{*}$ & \\
& 2 & $0 / 11$ & \\
& 3 & $0 / 8$ & $0 / 30$ \\
\hline
\end{tabular}

* Five were given $60 \mathrm{mg} / \mathrm{kg}$; all others were given $120 \mathrm{mg} / \mathrm{kg}$.

The results of the first series of experiments are seen in Table 1 . At $15 \mathrm{mg} / \mathrm{kg}$ or more, there was no apparent relationship of dose to lethality. Overall mortality was $49 \%$. In the second series of experiments (Table 2), the death rate varied considerably among different groups of conventional animals but the overall mortality was $52 \%$, a result similar to that of the first experiment. Most deaths occurred between 3 and 5 days after penicillin injection. None occurred earlier than 3 days and only one as late as 8 days. Death was preceded by the appearance of listlessness, weight loss, weakness, and ruffled fur. Autopsy was performed on four conventional animals that died. A hemorrhagic colitis was seen in three. Cultures of blood as well as stains and cultures of tissue revealed no bacteria, except for one guinea pig from which Escherichia coli was recovered from heart blood.

In contrast, none of 30 germ-free animals died in an observation period of 2 weeks, and their outward appearance remained normal.

The absence of lethality of penicillin for germ-free guinea pigs is compatible with the hypothesis that the drug kills through some indirect effect on the intestinal flora. The lack of a typical dose effect on mortality and the fact that death did not occur until at least 3 days after a single injection, or long after the bulk of the drug would have been excreted, also suggest that the effect of the drug is not directly pharmacological.

It is of interest that not only penicillin but also a number of other antibiotics manifest an increased toxicity for guinea pigs as compared with other animals (Eyssen et al., Antibiot. Chemotherapy 7:55, 1957). The mechanism of this indirect toxicity in the guinea pig appears to be complex. Although overgrowth of $E$. coli has been observed in moribund animals given antibiotics, death did not result when intestinal infection with $E$. coli was deliberately established in previously germ-free guinea pigs (Phillips et al., Am. J. Trop. Med. Hyg. 4:675, 1955; Formal et al., J. Bacteriol. 82:284, 1961). This observation suggests that additional factors may be involved. Pertinent perhaps are recentstudies which indicate that the numbers and composition of the intestinal flora can effect the reaction of some animals to bacterial endotoxins (Jensen et al., Proc. Soc. Exptl. Biol. Med. 113:710, 1963).

\title{
REDUCTION OF VITAMIN B B $_{12}$ BY PSEUDOMONAS RUBESCENS
}

\author{
J. B. HUFHAM, R. C. BURGUS, W. M. SCOTT, AND J. J. PFIFFNER \\ Department of Physiology and Pharmacology, Wayne State University \\ College of Medicine, Detroit, Michigan
}

Received for publication 28 March 1964

While studying the degradation of vitamin $B_{12}$ by microorganisms, we observed that the red color of the vitamin was initially converted to a yellow or yellow-brown product(s) by Pseudo- 